\title{
Computer Based Learning Development Efforts as Information and Communication Technology in Group B Kindergarten in Blitar
}

\author{
Linda Dwiyantia ${ }^{\mathrm{a}}$ Emi Nurniati ${ }^{\mathrm{b}}$ \\ aProdi PG-PAUD FKIP Universitas Nusantara PGRI Kediri \\ bPAUD LAB SCHOOL UN PGRI Kediri \\ Corresponding e-mail: lynda07adyaksa@gmail.com
}

\begin{abstract}
The purpose of this study is an attempt being made to educate the nation's children in order to achieve advanced life through the realization of a learning atmosphere that the activity of learning interesting and fun, as well as the educational process in a creative, innovative and interactive. Understanding the importance of early recognition technology is still low, is a cause in the development of education. The main target in the future of education is to prepare the future generation that is able to compete, and excel and not lagging behind in the progress of time. Advancement of information and communication technology today has influenced a wide range of areas, such as defense and security, trade, health, and education, including early childhood. The concept of the introduction of the "Computer" in learning is one aspect of development in early childhood education. One of the learning environments was instrumental in facilitating the mastery of learners towards competence is the application of technology in the use of instructional media. The problem of this study is whether via computer-based learning to develop Information and Communication Technology Kindergarten in Blitar. This study uses classroom action research steps are performed: 1) planning; 2) implementation; 3) observation; 4) reflection. Data analysis technique used is descriptive qualitative analysis. The conclusion of this research is through cycles of action learning through computer media is proven to develop the information technology and communication in group B kindergarten children in Blitar.
\end{abstract}

Keywords: Computers, ICT, Kindergarten

\section{INTRODUCTION}

Along with technological advances globalized been that influent in all aspects of life both in economic, political, cultural arts and even in the world of education. In an effort to improve education are being made to educate the nation's children in order to achieve progress through the life of the embodiment atmosphere for learning interesting and fun learning activities, as well as the process of creative education. Understanding the importance of early recognition technology is still low, is a cause in the development of education. A central goal of education is to prepare the future generation that is able to compete, excel. Shanti (2014) states that education as the foundation of development of a nation requires renewal in accordance with the demands of the times. Success in education is always closely linked with the progress of a nation that affects the growing prosperity of people's lives. In the era of high-tech development and transformation of knowledge goes so fast. As a result, the conventional education system would not be able to follow the development of science and technology. Modern approaches in the teaching process will not be much help to pursue the development of science and technology if the education system is still done conventionally. The need for mastery of ICT to anticipate technology approach to basic education up to college is expected to improve the quality of teaching process, the quality of assessment of student progress, and the quality of school administration.

The education must be willing to hold a positive innovation for the advancement of education and school. Not only innovation in the 
curriculum field, facilities, thorough innovation using information and communication technology in educational activities. Educational technology can change the way conventional to non-conventional learning. Learning is a process of creating an environment that enables the process of learning. The learning process in question is the child's activity in interacting with the environment that will result in behavior which is constant. Advancement of information and communication technology today has influenced a wide range of areas, such as defense and security, trade, health, and education, including early childhood. The concept of the introduction of the "Computer" in learning is one aspect of development in early childhood education. One of the learning environments was instrumental in facilitating the mastery of learners towards competence is the application of technology in the use of instructional media.

Early Childhood Program is one of the priority programs of the Ministry of Education. Because of early childhood in $0-6$ years is the most potential to build and develop the children potential according to Montessori (in Sujiono, 2010: 54). Early childhood is a very important age for the development of socalled golden age children. Childhood is in the growth stage and it's most rapid development, both physically and mentally. Early Childhood learning in its own way because of their personalities could not be set to maximum. Be patience that should be prioritized. To learn quickly that usually the child feels saturated. They prefer to play and things that are fun. By changing the mindset of learning by using computer-based learning as an effort to develop Information and Communication Technology Education as the use of animated pictures expected that children can enjoy it as well to demonstrate what. Children usually love to see moving images rather than still images.

In order to create a model learning active and innovative, the computer-based learning is very important in the education world view today's technology has been growing rapidly in every country, therefore, as an educator must develop each learning media.

\section{LITERATURE REVIEW}

\subsection{Media}

The word comes from the Latin media is Medium, which means an intermediary or introduction. The media is an extension of man that may affect others who have not entered into direct contact with him,
Marshal McLuhan (in Trianto, 2009: 234). According Trianto (2009: 234) learning media is as a messenger (the carries of messages) on some channel sources to the receiver (the receiver of messages). Learning media is anything that can be used to deliver a message from the sender to the receiver so that it can stimulate the mind, feelings, concerns and interests, as well as a child's attention so that the learning process occurs. The role of media in learning, especially in early childhood education is increasingly important given the child's development at that time was at the time of concrete thinking.

Therefore, one of the principles for early childhood education should be based on reality; it means that the child is expected to learn something real. Thus in early childhood education should use something that allows children to learn in a concrete way. That principle implies the need to use the media as a channel transmitter of messages for early childhood education.

\subsection{Computer}

According vivi (2012) "Computer in modern era led as electronic devices that can perform multiple tasks and has many functions". The term computer comes from a Latin is computer means to count and in English can be called to compute, which is initially targeted at those who counting and after it was addressed to a mechanical calculators ago with the development of a tool privileged capable of doing things amazing. Definition of a computer can be translated as a set of electronic tools that each other's work together coordinated under program control with the ability to be able to receive data (input) and data processing (process) with generating information (output).

Computers are not only beneficial for adults but it is now very beneficial for early childhood. The use of multimedia in children who applied to the computer a positive effect related to the ability of the concept of language, cognitive, social, emotional, religious and moral values, the motor, and the art of children. Computers are one of the latest innovations in early childhood class would not hurt since a small child begins to know and know what a computer is through animated images, voice will be clearer for children, Diane Trister (in Rochanah, 2015: 3). This computer can be done through play. Computer 
games on children should also be adjusted child characteristics and patterns of child development. Computer games specifically intended that the child is able to operate a computer in accordance with the characteristics of the child, moving the mouse and can also train the coordination between eye and hand so the integration between the hand and the eye so that the child's development can run optimally, because the more senses a child stimulated coordinated the more developed the aspects of aspects of child development. Computers are a great resource to access benefits information at this time, and can also be used to view the photographs, writing stories and playing games (according to Vygotsky's theory).

According Radhiatuljanah (2014), based on the phenomenon of early childhood environments and instruments to support the understanding and knowledge of the development of information and communication technologies. The relationship between the environment and the use of computers is to explore the relationship between:

- Object (or actions, events, etc.),

- Pictures (fixation realistic),

- Icon (symbolic picture)

- Oral Language,

- Writing languages,

Benefits of computer education for early childhood:

\section{a. train Logic}

While playing the game, children must use a variety of strategies to win the game. It can train the use of logic, analyze, and solve the problems being faced.

b. Visual Spatial train

Through playing games, spatial abilities of children associated with the image of intelligence and visualization will be honed. This capability would interfere with their numeracy skills. In addition, the game will also help use fine motor skills of children.

\section{c. Literacy}

For children who are not yet fluent in reading, gaming consoles could be the right tool to help learn to read. As known there are some games there are education and can help children to learn in a way that is more fun. Moreover, when the children' playground are also required to read any instructions given by the game characters and the narrator of the game. So, indirectly, children can learn to read and spell significantly.

d. Brain stimulation

In the game there are games that can make the game itself in accordance with what he wanted. It can help stimulate the brain and thought processes of creating long and complex scenarios as part of the development of their creativity

e. Developing Imagination

The game can help children to develop their imagination. Children can use the imagination to balance the various events in the film and in real world applications (relevant and positive)

f. Understanding of the English language

One child is the preferred game consoles and online games. This game was made by a lot of overseas companies who will be in English. When playing, are required to master the English language in order to finish the game. This makes the child is not directly required to master English

The implications of the use of computers as an ICT. In addition to the benefits that have been granted computer technologies, in particular technological development in this era globalists are also negative impacts of these developments while negative impact are as follows:

According to (Chiba Takeo, et. Al. 1997). Generally a computer, it is assumed that the impact on personal relationships natar child to the other premises become weak because of poor children communicate when they use the computer.

Meanwhile, according to (Personal, et al, 2010) are:

a. The computer can lead to eye on a child becomes ill when too long in front of computers.

b. Computers also can cause children lazy to learn, if the child is familiar with online games.

c. Most likely the child eating game that includes elements of violence without parental consent.

d. Children will lose playing time with friends his age that would make the lack of balance the social life of the child.

e. Children also become lazy to learn as much time spent in front of the computer, resulting in decreased academic achievement. 
f. Internet access will also have a negative impact when in fact; capable of accessing the Internet is a good start for the development of the child insight. Children will be threatened by much bad information flooding the internet.

g. Detrimental to health, for example, repetitive stress or strain injury, eyestrain and headaches, back and neck pain, and so forth.

\subsection{Information and Communication Technology}

Information Communication and Technology is a system or technology that can reduce the restrictions of space and time to pick up, move, analyze, display, store and deliver data into information. More common understanding of the term led to the development of computer technology and telecommunications / multimedia (in various forms), which already has a wide range of capabilities as a data processing / information, control devices, communication devices, media education, entertainment and others. From the definition of key technologies in the ICT and IT Domain is clear that information technology cannot be released to computer technology and telecommunications. With the enactment of Law No. 20 In 2003, the education system in Indonesia consists of early childhood education, elementary education, secondary education and higher education which are all systemic unity. Early childhood education held before the basic education level. ECCE into education or informal form from family education organized by the education environment. In an effort to provide guidance to the units of early childhood, the necessary existence of a motion how the application of ICT in learning in early childhood learning remember is to have fun, play while learning, and learning while playing. We should know that the goal of ICT in early childhood is introducing information and communication technology including introduction to computers. At the stage of early childhood, the child is still within the limits of introducing computers, parts and functions of the computer itself, using a computer properly, such as how to turn on and turn off the computer, orderly using a computer. a) ICT as a learning resource

ICT as a learning resource, are:

1. Answering the Needs Information:

$\checkmark \quad$ Integrating ICT as learning source

$\checkmark \quad$ Ensure the addresses of sites that will be visited

$\checkmark \quad$ Creating self-reflection sheets

2. The Service Fast and Cheap include;

$\checkmark \quad$ Leave the habit of learning resources

$\checkmark \quad$ Using various learning resources

$\checkmark \quad$ Making use of internet

3. Current Information

$\checkmark \quad$ Provide current information / new

$\checkmark \quad$ FAST (interconnection to all systems in library connection)

$\checkmark \quad$ CURRENT (Information regularly updated)

b) ICT as a learning medium

ICT as a medium of learning:

The ultimate goal is prevent the message conveyed easily understood by learners,

The purpose of ICT as a learning medium:

- To provide a different learning experience

- Growing attitudes and skills

- Creating a fun learning situation

- $\quad$ To make learning more effective, efficient and meaningful

- $\quad$ Provide to the students' learning motivation

- Create learning as a requirement

So, it can be said that the main purpose of ICTs in Learning is so easy to understand the messages conveyed by learners, especially for children's learning. Learning basic ICT is a learning approach to optimize the use of information and communication technology as a learning resource and as deliver messages in learning Interest Application of Information Technology and Communication in Education Early Childhood Education.

Munir (2009: 33) in his said purpose of studying Information and Communication Technology, among other:

a. In Cognitive Aspects

May know, know, or understand the information and communication technology. To 
improve learning in technology, and to improve scientific thinking skills at a time of preparation for education, job retention, and society role in the future.

\section{b. On Affective Aspects}

The student can be active, creative, appreciative and independent in the use of information technology and communication while also data respect of copyright works in the field of information and communication technology.

\section{c. Aspect Psychomotor}

The student is able to skillfully take advantage of information and communication technology for learning in everyday life. Students' ability and interest of the learner to technology. Ruan scope of information and communication technology covers the following aspects of the hardware and software used to collect, store, manipulate and present information. Among the hardware and software are tools for processing telecommunications and move data to device from one other devices.

Based Rachel (2004: 1) in early childhood education (ECE), the term information technology and communication may include the following types, namely hardware and software:

- Computers (including desktops, laptops, and handheld computers);

- Digital cameras and digital video cameras;

- Creativity and communication software and tools; internet;

- $\quad$ Phone, fax machines, mobile phones, tape recorders;

- The story interactive, simulated environments, and computer games;

- Toys programmable and "control" technology;

- Technology Video conferencing and closedcircuit television;

- Data projector, electronic whiteboard, and more.

Function and scope of the role of ICT in early childhood education.

The importance of using ICT in learning considering the potential of ICT, are:

1. Creating an abstract concept concrete example to explain the circulatory system.
2. Bring an object that is dangerous or difficult to come into a learning environment, for example: the animals' fruit or penguins from the South Pole.

3. Displays objects that are too large, for example, the market and all sorts of animals.

4. Changing the movement is too fast, for example by slow mention or time lapse photography

5. Allow the child to interact directly with their environment

6. Enable to uniformity of perception and observation for a child's learning experience

7. Generating children's learning motivation

8. Presenting learning information in a consistent, accurate, and repeatable quality or saved by its use as needed

10. And the widespread ICT education can broaden learning opportunities, improve the quality and efficiency of learning, enable to occurrence of self-learning and cooperative learning, and promote the establishment of lifelong learning. The function and role of ICT in early childhood In the era of globalization, the government is promoting the importance of early childhood education. To create generations that are superior, also will be able to competence in the future when they grow tall and also not forgetting the moral values and culture of Indonesia. Because of early childhood is a golden age. Where the formation of the growth and brain development in early childhood period of about 0-8 years to reach $80 \%$ growth and development of the human brain.

It was like a sponge and quickly they are able to absorb knowledge or whatever they receive, given the environment during growth and its development. But we should not forget the duties and obligations of the rights of children are playing while learning. Because the atmosphere of playing while learning does not make the child feel pressured or stressed on the circumstances of those who are studying themselves and also the environment. But the child will have the ease in learning in an atmosphere of play, fun and without pressure. That is why it is said a child's world is a world of play.

We cannot deny in any field of ICT has become a staple in our lives. Include in education. 
ICT has an important role in the learning infrastructure. The purpose of ICT in early childhood is introducing information and communication technology. To facilitate early childhood in helping the process of learning in a fun, creative, imaginative using ICT as a learning resource, such as an interactive $\mathrm{CD}$ that is now increasingly developing in the modification of the contents of learning. For example: learning to count, learning to read, recognize letters, recognize colors, geometry, shapes, also familiar with the environment, animals and plants as well as others. There is also a games-game that delights children but also the requirements to learning such as puzzle letters. So unwitting children, they learn a lot of familiar vocabulary in English, menagerie how to count. At the present time many parents forcing children to learn without thinking about the needs and rights of children in the world are playing.

By using this facilities and infrastructure of ICT as a learning resource it can make learning more attractive and creative. Make children become more challenged to play while learning. Children's early childhood is very quick and easy to learn while playing, which sometimes we as parents or as well as early childhood educators. Not to be forgotten monitoring in learning using ICT learning resources. That children are not far off from the introduction of learning we expect on the original purpose of making ICT as a learning resource that is suitable and appropriate for young children. Because of we all know where besides ICT has a positive impact in helping the growth and development of children in the study, also had a negative impact if we are not unmindful of the supervision or in learning using ICT. Therefore, it should be everything related to the development of ICT learning, children need supervision and learning balanced with mental and learning needs, so that children or learners are not wrong to use the use of learning technology developments.

\section{METHOD}

The study was designed using design class action (PTK), which is a form of research to undertake corrective measures in order to improve or enhance classroom practice more professionally. According to Akbar (2009: 28) PTK is a controlled process of investigation to find and solve problems in the classroom. PTK be gradual and cyclical, in order to determine the increase in the ability of all children in one class rather than individuals. PTK is done collaboratively, which is the core of teachers as implementers of learning and research as an observer (observer). PTK is done by: 1) the action planning; 2) implementation of the action; 3 ) observation; 4) acts of reflection. This activity is called a cycle, according to the model cycle according Arikunto (2010: 137). This study held second semester in year 2015/2016.

The subjects were children in group B TK Negeri Pembina Blitar with the number of 15 children consisted of 10 boys - boys and 5 girls. Research in the B group aims to increase the ability to improve the information technology and communication. Data collection techniques used in this study is the observation and documentation. Research Instruments determine the level of ability in accepting the learning activities. Consists of: 1) RPPM; 2) RPPH; 3) Indicators.

\section{CONCLUSIONS}

The conclusion of this study is to show that ICT is increasingly becoming an important tool and an integral part of the work of educators and cultural professionals. ICT reached a crucial role, by providing alternative opportunities to explore their creativity, build a concept and critical reflection. Computers can be used as a companion authority in the development and construction of knowledge children to interact with various media and languages, reflecting the dimensions of cognitive and social-emotional learning and its relation to knowledge.

After carrying out an evaluation of learning after the implementation of the action and examines the problems that occurred earlier on how to teach and integrate media for learning. Gains should be quantified and presented as a value-added medium of learning for pre-school. With different methods of presenting educational content that is appealing to children. The proper use of a computer proved to be able to develop information and communication technologies for group B in Kindergarten in Blitar among developing knowledge and skills such as language development and writing, written language, the introduction of the concept of 
cognitive ability Value of Religious and Moral, as well as stimulating the imagination and creativity, develop cooperation with friends, fine motor skills train hand-eye coordination.

\section{REFERENCES}

Arikunto, Suharsimi. (2010). Prosedur Penelitian Suatu Pendekatan Praktik. Jakarta: PT Rineka Cipta

Akbar, Sa'dun. (2009). Penelitian Tindakan Kelas (Filosofi, Metodologi, \& Implementasi). Yogyakarta: Cipta Media Aksara

Luluk Rochanah. (2015) .Pemanfaatan Media Berbasis Komputer Untuk Meningkatkan Kemampuan Mengenal Huruf Pada Anak Usia Dini. Jurnal Selling: Volume1 Nomor 1

Munir. 2009. Pembelajaran Jarak Jauh berbasis Teknologi Informasi dan Komunikasi. Jakarta: alfabeta.

Sujiono, Y. N. (2010). Bermain Kreatif Berbasis Kecerdasan Jamak. Jakarta: PT Indeks

Trianto. (2009). Mendesain Model pembelajaran Inovatif- Progresif. Jakarta: Prestasi Pustaka.

Datuk P. 2016. Improving ICT usage in early childhood education

www.mambolook.com/southeasasia/education/early-childhood (access on $10^{\text {th }}$ of August 2016 at $9.00 \mathrm{pm}$ )

UU No. 20 Tahun 2003 tentang Sistem Pendidikan Nasional dan UU No. 14 Tahun 2005 tentang Guru dan Dosen. Jakarta: Visimedia

Vivi Angraini. 2012. Pentingnya Pendidikan Komputer Anak Usia Dini. http://vivianggraini831.blogspot.co.id/2012/11/ artikel-pendidikan-komputer-anak-usia.html (access on $10^{\text {th }}$ of August 2016 at 9.15 pm)

Chiba Takeo, et al. 1997. Creative Practical Use of Digital Media in Early Childhood Education Part 1. Volume 29.

Radhiatuljanah.2014.Mengenalkan Teknologi Komputer Pada Anak Usia Dini. http://radhiatuljanah.blogspot.co.id/2014/05/no rmal-0-false-false-false-in-X-none-x.html (access on $15^{\text {th }}$ of August 2016 at $9.00 \mathrm{pm}$ )

http://www.education.govt.nz/earlychildhood/teaching-and-learning/learningtools-and-resources/play-ideas/ict/ (access on $15^{\text {th }}$ of August 2016 at $9.30 \mathrm{pm}$ )

http://myblogtesayulia.blogspot.co.id/ (access on $21^{\text {st }}$ of August 2016 at $9.00 \mathrm{pm}$ ) https://shantivisioner.wordpress.com/2014/02/24/pe nerapan-pengajaran-berbasis-tik/ (access on $24^{\text {th }}$ of August 2016 at $9.00 \mathrm{pm}$ ) 